Miguel Blanco Canto, D.Sc., Assistant Lecturer, Department of General Economic, University of Cadiz,

Cadiz, Spain

Lydia Bares Lopez,

Ph.D., Lecturer of Economics, Department of General Economic, University of Cadiz,

Cadiz, Spain

\title{
RANKING OF GLOBAL EFFICIENCY OF THE BEST UNIVERSITIES IN EUROPE
}

In any economic organization, the existing relationship between its inputs and its outputs must be established in such a way that the management of its tangible and intangible human resources allows producing the maximum amount of useful products with the least amount of resources. In this article, we have analyzed this relation of efficiency applied to the university environment. In particular, the best universities in Europe have been studied. Previously, a rigorous study of the existing bibliography has been carried out. As a result, it has been seen that these studies include specific results analysis, without taking into account the three basic functions of 21st century universities, such as those related to improving the employability of their graduates, transmitting and expanding their scientific knowledge, and the modernization of the national economic system through the introduction of improvements in business activity. The methodology used in is data envelopment analysis (DEA). This model has allowed determining the relative position of each university in relation to the distance it maintains with respect to an ideal efficiency frontier. It also shows that aspects must be improved to be in a position of maximum efficiency. Four types of analysis have been applied. DEA 1 "Analysis of labor efficiency" in which the improvement of the degree of employability of university graduates has been analyzed, DEA 2 "Analysis of academic efficiency" that has allowed us to measure the efficiency in publications, the DEA 3 "Analysis of technological efficiency "that has allowed identifying the universities that are more efficient in terms of patents and finally DEA 4" Global efficiency analysis "that encompasses all the previous ones. Likewise, a correlation analysis was carried out among the results obtained. Among the main conclusions highlight how there is a high degree of correlation between the universities that achieve the best results in academic efficiency and technological efficiency. The comparisons in the level of global university efficiency made in this research work are the result of applying the DEA methodology on a production function that has been constructed using four variables inputs - undergraduate and graduate students and national and foreign teachers - and three output variables - levels of employment, publications and patents.

Keywords: ranking, university, employability, data envelopment analysis, patents, publications.

Formulation of the problem generally. Efficiency is a business concept that defines the relationship between inputs and outputs. In their management, organizations must make decisions that involve producing the maximum amount of products using the minimum possible amount of inputs. To do this, they have to take three types of decisions (Arcos et al., 1993 [1], Alvarez, 2001 [2]):

- Choose the output that maximizes the benefit of all possible production levels (scale efficiency);

- Choose the optimal combination of inputs that minimizes production costs among all possible combinations of inputs necessary to obtain the product (allocative efficiency);

- Produce the product using the minimum possible quantity of inputs (technical efficiency).

For the study of these three types of efficiency, it is usual to resort to the border model. This model implies defining a production, benefit or cost function through techniques that can be parametric or nonparametric. 
The production function must allow determining the theoretical maximum product that can be reached from a given combination of inputs (Farrell, 1957 [3]). Once defined, comparisons can be made between a set of organizations or Decision Making Units (DMU) based on their greater or lesser proximity to the production frontier. Thus, by using this type of efficiency analysis, one can compare the actual situation of an organization with respect to an optimum and conclude whether or not an organizational unit is effective in relation to its location on the production, benefits or costs frontier. If it falls below this function or is above the cost frontier, the entity is inefficient (Buchelli and Marín Restrepo, 2012 [4]).

One of the main advantages of this model lies in the amount of information it provides starting from a moderate level of data since it works mainly by comparing decision units (Chirinos and Urdaneta, 2007 [5], Camilli, Vargas, Ryan, \& Barnett, W., 2010 [6]).

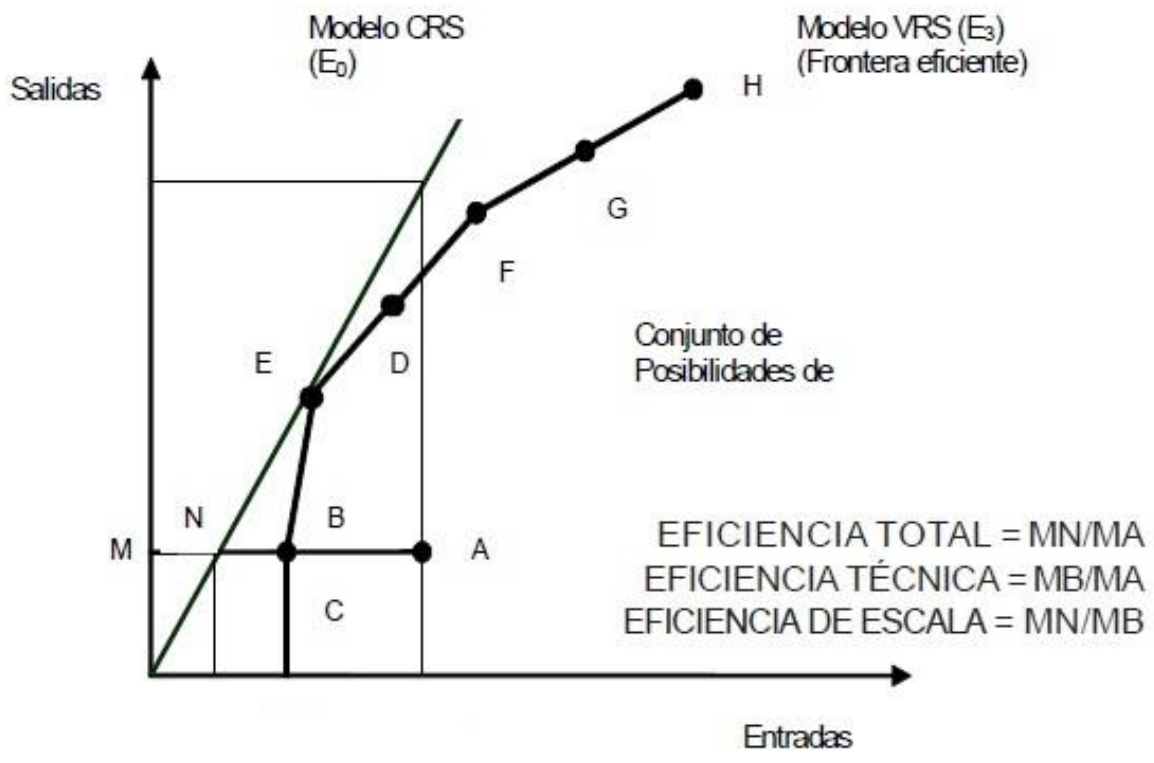

Figure 1 - Set of production possibilities and the different efficiencies

The overall efficiency is determined by the following equation (Model CCR):

$$
\text { Global efficiency }=M N / M A
$$

On the other hand, technical efficiency would be defined by (BBC Model):

$$
\text { Technical efficiency }=M B / M A
$$

Finally, the scale efficiency would be calculated as follows:

$$
\text { Scale efficiency }=M N / M B
$$

The relationship between them is determined by the following equation: 


$$
\text { Global efficiency }=\text { Technical efficiency } \times \text { Scale efficiency }
$$

In practice, it is interesting to know the efficiency of organizations since it is essential to increase their output without absorbing more than the resources necessary for it (Farrell, 1957 [3]). For this, the authors usually use different models, both parametric and non-parametric.

The determination of the efficient frontier, through the application of a non-parametric methodology, has some advantages over parametric models, fundamentally those derived from the need to determine a specific function that explains a certain behaviour through the definition of a set of variables dependent and independent. Using a non-parametric methodology, what is being determined is the relative efficiency of an organization in relation to others taken from a representative and homogeneous group (Maza, Vergara and Navarro, 2011 [7]).

One of the most widely used nonparametric models is the data envelopment analysis (DEA) proposed by Charnes, Cooper and Rhodes in 1978 [8]. Subsequently, Banker, Charnes and Cooper (1984) [9] developed a model that is known by the initials of its authors (BCC) similar to the previous one, but which includes a more flexible border. This fact made it quickly used by different authors in their efficiency analysis both in the purely business field and in the field of social organizations, among which are those related to teaching and research activity (Johnes and Li, 2008 [19], Bessent \& Bessent, 1980 [10] and Emrouznejad and Yang, 2017 [11]). The main reason lies in the fact that it allows the inclusion of multiple input and output variables, a situation that adapts to the reality of social organizations since they pursue multiple objectives that must be taken into account in the analysis of the determination of their levels of performance (Worthington and Dollery, 2000 [12], Zhonghua and Ye, 2012 [13]). In these cases, the efficiency of each decision unit (DMU) is obtained as:

$$
\text { Efficiency }=\frac{Y}{X}=\text { Output } / \text { Input }
$$

When more inputs are used, the equation would be the following:

$$
\text { Effiency }=\frac{a_{i} Y_{i}}{b_{i} X_{i}}
$$

Analysis of recent researches and publications. The use of this model implies, in the first place, to define a series of variables inputs/outputs. To this end, an exhaustive analysis of the available literature

\begin{tabular}{|c|c|c|}
\hline Author & Inputs & Outputs \\
\hline 1 & 2 & 3 \\
\hline $\begin{array}{lr}\text { Abbott } & \& \\
\text { Doucouliagos [14] }\end{array}$ & $\begin{array}{l}\text { Total number of academic staff (full-time equivalent) } \\
\text { The number of non-academic staff (full-time equivalent) } \\
\text { Expenditure on all other inputs other than labour inputs } \\
\text { Non-current assets }\end{array}$ & $\begin{array}{l}\text { Teaching output includes the number of } \\
\text { equivalent full-time students, the number of } \\
\text { post-graduate and under-graduate } \\
\text { degrees enrolled as well as the number of } \\
\text { post-graduate degrees conferred and the } \\
\text { number of undergraduate degrees } \\
\text { conferred EFTS is arguably the better } \\
\text { measure }\end{array}$ \\
\hline Avkiran [15] & $\begin{array}{l}\text { Academic staff FTE } \\
\text { Non-academic staff, FTE }\end{array}$ & $\begin{array}{l}\text { Overseas fee-paying enrolments, EFTSU } \\
\text { Non-overseas fee-paying postgraduate } \\
\text { enrolments, EFTSU }\end{array}$ \\
\hline
\end{tabular}
on DEA analysis in higher education has been carried out (Table 1).

Table 1 - Analysis of inputs/outputs by authors in DEA analysis applied to higher education 
table 1

\begin{tabular}{|c|c|c|}
\hline 1 & 2 & 3 \\
\hline $\begin{array}{l}\text { Bessent \& } \\
\text { Bessent [16] }\end{array}$ & $\begin{array}{l}\text { Pupil inputs measured by the California Achievement Test in } \\
\text { May } 1976 \text {. } \\
\text { X1 median percentile reading achievement for only those } \\
\text { pupils who attend school during the full year; X2 median } \\
\text { percentile mathematics achievement test score for only those } \\
\text { pupils who attend school during the full year. } \\
\text { Proxy measures for the neighbourhood and home conditions } \\
\text { (obtained from school district records) } \\
\text { X3 per cent of Anglo-American students; X4 per cent of } \\
\text { students that are not from low-income families; X5 per cent in } \\
\text { average daily attendance; X6 mobility index: (total enrollment } \\
\text { - the number of entered late or withdrawn)/total enrollment } \\
\text { Proxy measures for within school conditions (obtained from } \\
\text { school district records) } \\
\text { X7 number of professional staff per } 100 \text { pupils; X8 total per- } \\
\text { pupil expenditure for instruction } \\
\text { School organizational climate indicators obtained from the } \\
\text { Organizational Climate Description Questionnaire [10]; a high } \\
\text { score on each dimension indicates the following: } \\
\text { X9 esprit--an indicator of job satisfaction; X10 intimacy--an } \\
\text { indicator of how much social interaction exists among } \\
\text { teachers;X11 thrust--principal motivates teachers by personal } \\
\text { example of work orientation; X12 consideration-- a measure of' } \\
\text { the principal's friendliness and cooperativeness with teachers } \\
\text { A measure of classroom instructional processes (obtained from } \\
\text { Individualization of Instruction Inventory [10]; a higher score } \\
\text { indicates a greater degree of individual rather than group- } \\
\text { oriented teaching methods) } \\
\text { X13 total individualized instruction index }\end{array}$ & $\begin{array}{l}\text { Median percentile reading achievement } \\
\text { for only those pupils in attendance at the } \\
\text { school for a full year } \\
\text { Median percentile mathematics } \\
\text { achievement test score for only those } \\
\text { pupils in attendance for a full year }\end{array}$ \\
\hline $\begin{array}{l}\text { Chu } \\
\text { Li [17] }\end{array}$ & $\begin{array}{l}\text { Full sample inputs: Number of researchers; Number of } \\
\text { research supporting staff; Budget funds (in thousand RMB); (a) } \\
\text { In-budget; (b)Out-budget } \\
\text { East region inputs: Number of researchers; Number of } \\
\text { research-supporting staff; Budget funds (in thousand RMB); (a) } \\
\text { In-budget; (b) Out-budget } \\
\text { Central region inputs: Number of researchers; Number of } \\
\text { research-supporting staff; Budget funds (in thousand RMB); (a) } \\
\text { In-budget; (b) Out-budget } \\
\text { West region inputs: Number of researchers; Number of } \\
\text { research-supporting staff; Budget funds (in thousand RMB); (a) } \\
\text { In-budget; (b) Out-budget }\end{array}$ & $\begin{array}{l}\text { Full sample outputs: Number of } \\
\text { manuscripts; Number of articles; Number } \\
\text { of recognized research outputs; Number } \\
\text { of contracts; Number of prizes } \\
\text { East region outputs: Number of } \\
\text { manuscripts; Number of articles; Number } \\
\text { of recognized research outputs; Number } \\
\text { of contracts; Number of prizes } \\
\text { Central region outputs: Number of } \\
\text { manuscripts; Number of articles; Number } \\
\text { of recognized research outputs; Number } \\
\text { of contracts; Number of prizes } \\
\text { West region outputs: Number of } \\
\text { manuscripts; Number of articles; Number } \\
\text { of recognized research outputs; Number } \\
\text { of contracts; Number of prizesN }\end{array}$ \\
\hline $\begin{array}{l}\text { Correas and } \\
\text { Jorge [18] }\end{array}$ & $\begin{array}{l}\text { Personal expenses } \\
\text { Current expenses in goods and services } \\
\text { Lecturers' expenses } \\
\text { Other expenses }\end{array}$ & $\begin{array}{l}\text { No. of students enrolled } \\
\text { No. of graduate students } \\
\text { No. of the Ph.D. thesis } \\
\text { No. of publications } \\
\text { No. of scientific documents in indexed } \\
\text { journals } \\
\% \text { of teaching staff with one or more } \\
\text { research sections } \\
\text { No. of research projects } \\
\text { Patents applications } \\
\text { No. of spin-offs }\end{array}$ \\
\hline
\end{tabular}


table 1

\begin{tabular}{|c|c|c|}
\hline 1 & 2 & 3 \\
\hline Johnes, \& Li [19] & $\begin{array}{l}\text { Staff time is the full-time staff ti student ratio. Quality of the staff } \\
\text { inputs is reflected by the percentage of the faculty with associate } \\
\text { professor. Doctoral students. Research expenditure. Books is } \\
\text { an index of library books (derived from an unweighted average } \\
\text { of the indexes formed from total and per student } \\
\text { numbers.Buildings }\end{array}$ & $\begin{array}{l}\text { Index of the total numbers of research } \\
\text { publications. Research publications per } \\
\text { members of academic staff }\end{array}$ \\
\hline Johnes [20] & $\begin{array}{l}\text { A total number of FTE undergraduate students studying for a } \\
\text { first degree multiplied by the average A-level points for first-year } \\
\text { full-time undergraduate students (A level score is averaged over } \\
1994 / 95,1995 / 96,1996 / 97 \text { and } 1997 / 98 \text {. Note that } A=10, B=8 \text {, } \\
C=6, D=4, E=2 \text { ). } \\
\text { A total number of FTE postgraduate students. } \\
\text { A total number of full-time academic staff for teaching or } \\
\text { teaching and research or research only purposes. } \\
\text { Total depreciation and interest payable in } £ \text {. } \\
\text { Total expenditure on central libraries and information services, } \\
\text { and on a central computer and computer networks excluding } \\
\text { academic staff costs and depreciation in } £ \text {. } \\
\text { Expenditure on central administration and central services } \\
\text { excluding academic staff costs and depreciation in } £ \text {. }\end{array}$ & $\begin{array}{l}\text { Total number of first degrees awarded } \\
\text { weighted by degree classification } \\
\text { A total number of higher degrees } \\
\text { awarded (includes both doctorate and } \\
\text { other higher degrees). } \\
\text { Value of the recurrent grant for } \\
\text { research awarded by the Higher } \\
\text { Education Funding Council for England } \\
\text { (HEFCE) in } £ \text {. }\end{array}$ \\
\hline $\begin{array}{l}\text { Köksal, } \\
\text { Nalçaci [21] }\end{array}$ & $\begin{array}{l}\text { Academic staff salaries. Potential of the department. Entering } \\
\text { students }\end{array}$ & $\begin{array}{l}\text { Research activities and quality. } \\
\text { Education activities and quality.Other } \\
\text { activities. Graduates }\end{array}$ \\
\hline $\begin{array}{l}\text { Kuah, } \quad \& \\
\text { Wong [22] }\end{array}$ & $\begin{array}{l}\text { Teaching efficiency: A number of academic staffs/ Number of } \\
\text { taught course students/ Average students qualifications/ } \\
\text { University expenditures. } \\
\text { Research efficiency: University expenditures/ Number of } \\
\text { research staffs/ Average research staffs qualifications/ Number } \\
\text { of research students/ Research grants }\end{array}$ & $\begin{array}{l}\text { Teaching efficiency: Number of } \\
\text { graduates from taught courses/ } \\
\text { Average graduates results/ Graduate } \\
\text { rate/ Graduate employment rate } \\
\text { Research efficiency: Number of } \\
\text { graduates from research/ Number of } \\
\text { publications/Number of awards/ } \\
\text { Number of intellectual properties }\end{array}$ \\
\hline $\begin{array}{l}\text { Lee } \quad \& \\
\text { Worthington }[23]\end{array}$ & FTE Academic. PhD students & Publications indicator. Grants Students \\
\hline $\begin{array}{l}\text { Leitner, } \\
\text { Prikoszovits, } \\
\text { Schaffhauser- } \\
\text { Linzatti, } \\
\text { Stowasser \& } \\
\text { Wagner [24] }\end{array}$ & Staff. Room Space & $\begin{array}{l}\text { Examinations. Finished supervised } \\
\text { diploma theses. Monographs. Jornal } \\
\text { papers. Project reports.Presentations. } \\
\text { Other publications. Finished supervised } \\
\text { PhD theses. Patents. Financial funds } \\
\text { provided by Third parties. Finisher } \\
\text { projects ad personam.Finished projects } \\
\text { of the department }\end{array}$ \\
\hline Martí et. al. [25] & $\begin{array}{l}\text { No. of students enrolled. Current expenses. No. of full-time } \\
\text { lecturers }\end{array}$ & $\begin{array}{l}\text { No. of graduates. Revenue from } \\
\text { research. No. of the Ph.D. thesis }\end{array}$ \\
\hline Martín [26] & $\begin{array}{l}\text { No. of full-time lecturers. No. of part-time lecturers. No. of full- } \\
\text { time equivalent lecturers. No. of permanent lecturers. No. of } \\
\text { non-permanent lecturers. No. of scholars. Lecturers' salary. No. } \\
\text { of students. Teacher load. Infrastructures. No. of computers. } \\
\text { Physical investment. Budget. External aid for research. } \\
\text { Expenses in books and magazines }\end{array}$ & $\begin{array}{l}\text { No. of students. No. of graduates. The } \\
\text { average score in the evaluation survey. } \\
\text { Teachers' load. No. of publications. } \\
\text { External aid for research. No. of the } \\
\text { Ph.D. thesis. No. of citations }\end{array}$ \\
\hline $\begin{array}{l}\text { Taylor } \\
\text { Harris [28] }\end{array}$ & $\begin{array}{l}\text { Total expenditure. Capital employed. Capital employed and } \\
\text { student numbers. Capital employed and staff numbers. Capital } \\
\text { employed and adjusted expenditure. Capital employed and total } \\
\text { expenditure. Student numbers and staff numbers. }\end{array}$ & $\begin{array}{l}\text { Academic qualifications completed } \\
\text { (degrees, diplomas and certificates). } \\
\text { Research output (books, articles in } \\
\text { approved journals, conference } \\
\text { proceedings, patents/licenses and } \\
\text { research income). }\end{array}$ \\
\hline
\end{tabular}


table 1

\begin{tabular}{|l|l|l|}
\hline \multicolumn{1}{|c|}{1} & \multicolumn{1}{|c|}{ 2 } & \multicolumn{1}{|c|}{3} \\
\hline $\begin{array}{l}\text { Sagarra, Mar- } \\
\text { Agasisti [27] }\end{array}$ & $\begin{array}{l}\text { Full-time equivalent faculty. Total enrolment. First joining } \\
\text { graduates }\end{array}$ & Scopus papers. Graduates \\
\hline Warning [29] & $\begin{array}{l}\text { Inputs used to measure staff, both scientific and non-scientific, } \\
\text { and overhead expenditures, including spending on library } \\
\text { resources, computing services and further infrastructure. }\end{array}$ & $\begin{array}{l}\text { It is based on the Science Citation } \\
\text { Index (SCI) data for the natural } \\
\text { sciences and on the Social Science } \\
\text { Citation Index (SSCI) and the Arts and } \\
\text { Humanities Index (AHI) for the social } \\
\text { sciences. } \\
\text { Since the ISI3 incorporates only quality } \\
\text { journals in its indexes, the computed } \\
\text { score provides information on both the } \\
\text { quality and quantity of publications. } \\
\text { The "publication" variable includes the } \\
\text { total number of publications from 1997 } \\
\text { to 1999, amounting to 14,176 in the SCI } \\
\text { and 893 in the SSCl and AHI }\end{array}$ \\
\hline $\begin{array}{l}\text { Wolszczak- } \\
\text { Derlacz [30] }\end{array}$ & $\begin{array}{l}\text { Model 1: Academic staff/ Total revenue/ Total numbers of } \\
\text { students.Model 2: Academic staff/ Total revenue. Model 3: } \\
\text { Academic staff/ Non academic staff, total revenues/ students. } \\
\text { Model 4: total revenues }\end{array}$ & $\begin{array}{l}\text { Model 1: publications/ graduates. } \\
\text { Model 2: publications/ graduates. } \\
\text { Model 3: scientific articles/publications } \\
\text { other tan scientific articles/graduates } \\
\text { Model 4: publications/graduates. }\end{array}$ \\
\hline
\end{tabular}

Unsolved issues as part of the problem. As can be seen, the major part of the bibliographic review includes only the university function as an element of creation and dissemination of science. However, it overlooks two objectives that are also important, such as improving the employability of its graduates and supporting business development.

Table 2 - Variables inputs/outputs used in the production function

\begin{tabular}{|c|c|c|c|}
\hline Type & \multicolumn{2}{|c|}{ VARIABLE } & DESCRIPTION \\
\hline 1 & \multicolumn{2}{|l|}{2} & 3 \\
\hline \multirow{5}{*}{ Output } & \multicolumn{2}{|c|}{ (0.1) (QS) Overall score } & $\begin{array}{l}\text { Overall score calculated for the indicator QS Graduate Employability. It is constructed } \\
\text { from the following variables: Employer reputation }(30 \%) \text {; Alumni outcomes }(25 \%) \text {; } \\
\text { Partnerships with Employers per Faculty (25\%);Employer/Student Connections (10\%); } \\
\text { Graduate employment rate (10\%) }\end{array}$ \\
\hline & \multirow{3}{*}{$\begin{array}{l}\text { (0.2) } \\
\text { Publicaciones }\end{array}$} & $\begin{array}{c}(0.2 .1) \\
\mathrm{HiCi}\end{array}$ & $\begin{array}{l}\text { The number of Highly Cited Researchers selected by Clarivate Analytics. The Highly } \\
\text { Cited Researchers list issued in November } 2016 \text { ( } 2016 \text { HCR List as of November } 16 \\
2016 \text { ) was used for the calculation of HiCi indicator in ARWU 2017. Only the primary } \\
\text { affiliations of Highly Cited Researchers are considered. }\end{array}$ \\
\hline & & $\begin{array}{c}(0.2 .2) \\
N \& S\end{array}$ & $\begin{array}{l}\text { The number of papers published in Nature and Science between } 2012 \text { and } 2016 \text {. To } \\
\text { distinguish the order of author affiliation, a weight of } 100 \% \text { is assigned for corresponding } \\
\text { author affiliation, } 50 \% \text { for first author affiliation (second author affiliation if the first author } \\
\text { affiliation is the same as corresponding author affiliation), } 25 \% \text { for the next author } \\
\text { affiliation, and } 10 \% \text { for other author affiliations. When there are more than one } \\
\text { corresponding author addresses, we consider the first corresponding author address as } \\
\text { the corresponding author address and consider other corresponding author addresses } \\
\text { as first author address, second author address etc. following the order of the author } \\
\text { addresses. Only publications of 'Article' type is considered. }\end{array}$ \\
\hline & & $\begin{array}{l}(0.2 .3) \\
\text { PUB }\end{array}$ & $\begin{array}{l}\text { Total number of papers indexed in Science Citation Index-Expanded and Social Science } \\
\text { Citation Index in } 2016 \text {. Only publications of 'Article' type is considered. When calculating } \\
\text { the total number of papers of an institution, a special weight of two was introduced for } \\
\text { papers indexed in Social Science Citation Index. }\end{array}$ \\
\hline & \multicolumn{2}{|l|}{ (0.3) Patentes } & Number of patents originating in each university \\
\hline
\end{tabular}


table 2

\begin{tabular}{|c|c|c|c|}
\hline 1 & & 2 & 3 \\
\hline \multirow{6}{*}{ Inputs } & \multirow[t]{2}{*}{ (I.1) Bachelor students } & (I.1.1) National bachelor students & \multirow{2}{*}{$\begin{array}{l}\text { Number of national and international } \\
\text { students enrolled in bachelor studies }\end{array}$} \\
\hline & & (I.1.2) International bachelor students & \\
\hline & \multirow[t]{2}{*}{ (I.2) Postgraduate students } & (I.2.1) National postgraduate students & \multirow{2}{*}{$\begin{array}{l}\text { Number of national and international } \\
\text { students enrolled in postgraduate } \\
\text { studies }\end{array}$} \\
\hline & & $\begin{array}{lll}\text { (I.2.2) International postgraduate } \\
\text { students }\end{array}$ & \\
\hline & \multirow[t]{2}{*}{ (I.3) Teaching staff } & (I.3.1) National teaching staff & \multirow{2}{*}{$\begin{array}{l}\text { National and international teaching staff } \\
\text { related to bachelor and postgraduate } \\
\text { studies }\end{array}$} \\
\hline & & (I.3.2) International teaching staff & \\
\hline
\end{tabular}

Aims of the article. The aim of the article is to carry out an overall efficiency analysis that includes three main functions of university management. We use information provided by QS Graduate Employability Rankings, Academic Ranking of the Universities of the World (ARWU) and the World's Most Innovate Universities.

Basic material. The following table includes the input/output variables used in the definition of the overall university efficiency production function.

The applied model aims to achieve the maximum amount of output given a certain level of inputs, under a restriction of ignorance of the technological level assumed by each University.

Therefore, it uses a variable-scale return model (VRS) proposed by Banker, Charles and Cooper oriented towards output (BBC-output model).

In this way, the problem to solve would be the maximization of the following expression:

Subject to:

$$
\operatorname{Max} y_{j}+\varepsilon\left(\sum_{k=1}^{s} h_{k}^{+}+\sum_{i=1}^{m} h_{i}^{-}\right)
$$

$$
\begin{gathered}
\sum_{j=1}^{n} \lambda_{j} * x_{i j}=x_{i j}-h_{i}^{-}, i=1, \ldots, m \\
\sum_{j=1}^{n} \lambda_{j} * y_{k j}=y_{k j} * y_{j}=\pi r^{2}+h_{k}^{+}, k=1, \ldots, m \\
\sum_{j=1}^{n} \lambda_{j}=1 \lambda_{j}, h_{i}^{-}, h_{k}^{+} \geq 0, \forall i, j, k y_{j} \text { is free }
\end{gathered}
$$

where: $y_{j}$ is the radial extension that occurs in all its outputs. It can be identified with the efficiency of $j$ if $j$ is compared with a point belonging to the efficient frontier; $h_{i}^{-}$is the rectangular reduction of the input $\mathrm{i} ; h_{k}^{+}$is the rectangular extension of the output $\mathrm{k} ; \lambda_{j}$ represents the coefficients of the linear combination of inputs and outputs to which the DMU projection point is referring, on the efficient frontier. It can be interpreted as the proximity of the DMU projection point, with respect to the efficient frontier.

In this way, the efficiency frontier would be integrated by all those efficient decision units. Once the border is determined by said entities, it compares each of the universities that are being studied with the border, under the assumption that the deviations detected indicate inefficient behaviour. In this way we can measure the relative efficiency of a set of DMUs that produce a type of output from a common set of inputs.

Four possible relationships of inputs/outputs have been analyzed (Table 3).

The universities that have been selected for the DEA analysis are those that occupy the top 40 positions in the ranking lists consulted. For this, it has been necessary that all of them were included in the three lists, which has been a limitation to apply the DEA model. The list is detailed in Table 4. 
Table 3 - Typology of DEA analysis performed

\begin{tabular}{|c|c|c|c|}
\hline & Type of analysis & Inputs & Outputs \\
\hline DEA 1 & Labour efficiency analysis & $\begin{array}{l}\text { (I.1) Bachelor students } \\
\text { (I.2) Postgraduate students } \\
\text { (I.3) Teaching staff }\end{array}$ & (0.1) (QS) Overall score \\
\hline DEA 2 & Academic efficiency analysis & $\begin{array}{l}\text { (I.1) Bachelor students } \\
\text { (I.2) Postgraduate students } \\
\text { (I.3) Teaching staff }\end{array}$ & (0.2) Publications \\
\hline DEA 3 & Technological efficiency analysis & $\begin{array}{l}\text { (I.1) Bachelor students } \\
\text { (I.2) Postgraduate students } \\
\text { (I.3) Teaching staff }\end{array}$ & (0.3) Patents \\
\hline DEA 4 & Global efficiency analysis & $\begin{array}{l}\text { (I.1) Bachelor students } \\
\text { (I.2) Postgraduate students } \\
\text { (I.3) Teaching staff }\end{array}$ & $\begin{array}{l}\text { (0.1) (QS) Overall score } \\
\text { (0.2) Publications } \\
\text { (0.3) Patents }\end{array}$ \\
\hline
\end{tabular}

Table 4-DMU's analyzed

\begin{tabular}{|c|c|}
\hline University of Cambridge & University of Amsterdam \\
\hline University of Oxford & Aarhus University \\
\hline ETH Zurich - Swiss Federal Institute of Technology & Trinity College Dublin, The University of Dublin \\
\hline Imperial College London & Erasmus University Rotterdam \\
\hline KIT, Karlsruhe Institute of Technology & The University of Sheffield \\
\hline The University of Manchester & University of Copenhagen \\
\hline Politecnico di Milano & Cardiff University \\
\hline Delft University of Technology & Ghent University \\
\hline University of Bristol & Maastricht University \\
\hline University of Nottingham & Universität Stuttgart \\
\hline The University of Edinburgh & Université Catholique de Louvain (UCL) \\
\hline The University of Warwick & Université Pierre et Marie Curie (UPMC) \\
\hline Technical University of Munich & Universidad Autónoma de Madrid \\
\hline University of Leeds & University of Glasgow \\
\hline University College Dublin & Technische Universität Dresden \\
\hline KU Leuven & University of Oslo \\
\hline University of Birmingham & Leiden University \\
\hline Universitat de Barcelona & Università di Padova \\
\hline RWTH Aachen University & University of Groningen \\
\hline University of Zurich & Universitat Politècnica de Valencia \\
\hline Alma Mater Studiorum - University of Bologna & Unampton \\
\hline
\end{tabular}

For the estimation of the global efficiency, variable returns to scale and an orientation towards the maximization of the selected outputs -patents, employment of its graduates and publications- according to a BBC-output model, without previous knowledge of the returns to scale that can be generated against the quantity of inputs applied in the maximizing production function.

DEA 1. Labour efficiency analysis. In this first analysis, DEA has made a study of university efficiency in labour insertion. The inputs used were the number of undergraduate students, the number of postgraduate students and the number of professors, distinguishing in the latter case between national and foreign professors. The output used is the QS Overall Score developed by QS Graduate Employability Rankings. The model used is the variable-scale return oriented output (BBC-output model), since it has been considered that the units analyzed would be more efficient if they managed to increase the score with a given number of inputs. In the model, the Cooper rule has been fulfilled, since we have worked with 4 variable inputs and one output variable. Therefore, $a>3$.

The results are shown in table 5 . In it, the DMU has been sorted according to the score. In addition, a column -target of university ranking- has been added, in which the level that should be increased by their QS Graduate Employability index to move to a situation of maximum efficiency is determined. 
Table 5 - Results of the application of the DEA model labour efficiency

\begin{tabular}{|l|c|c|l|c|c|}
\hline \multicolumn{1}{|c|}{ Unit Name } & Score & $\begin{array}{c}\text { Target QS } \\
\text { University } \\
\text { Ranking }\end{array}$ & & Unit Name & $\begin{array}{c}\text { Target QS } \\
\text { University } \\
\text { Ranking }\end{array}$ \\
\hline Università di Padova & 100 & 0 & Maastricht University & 74.98 & 33.37 \\
\hline Trinity College Dublin, the Univ & 100 & 0 & Technical University of Munich & 74.74 & 33.79 \\
\hline Politecnico di Milano & 100 & 0 & The University of Edinburgh & 74.6 & 34.05 \\
\hline Universitat de Barcelona & 100 & 0 & Rwth Aachen University & 74 & 35.14 \\
\hline Universität Stuttgart & 100 & 0 & Ku Leuven & 73.34 & 36.35 \\
\hline Universitat Politècnica de Valèn & 100 & 0 & Université Pierre et Marie Curie & 71.62 & 39.61 \\
\hline Kit, Karlsruhe Institute of Tech & 100 & 0 & University of Birmingham & 69.65 & 43.56 \\
\hline Delft University of Technology & 100 & 0 & University of Amsterdam & 68.06 & 46.93 \\
\hline Eth Zurich - Swiss Federal Insti & 100 & 0 & Aarhus University & 66.4 & 50.61 \\
\hline University of Cambridge & 100 & 0 & Erasmus University Rotterdam & 65.76 & 52.06 \\
\hline University of Oxford & 99.06 & 0.95 & Technische Universität Dresden & 63.8 & 56.75 \\
\hline Imperial College London & 89.33 & 11.94 & University of Zurich & 61.1 & 63.66 \\
\hline University College Dublin & 89.16 & 12.16 & The University of Sheffield & 59.27 & 68.71 \\
\hline University of Bristol & 87.03 & 14.89 & University of Southampton & 58.94 & 69.69 \\
\hline Alma mater Studiorum - Universit & 86.42 & 15.72 & Ghent University & 56.29 & 77.63 \\
\hline The University of Manchester & 84.69 & 18.08 & Cardiff University & 54.8 & 82.48 \\
\hline The University of Warwick & 81.27 & 23.05 & University of Copenhagen & 51.3 & 94.92 \\
\hline University of Nottingham & 78.95 & 26.66 & University of Oslo & 49.16 & 103.40 \\
\hline Universidad Autónoma de Madrid & 77.67 & 28.74 & University of Glasgow & 48.2 & 107.47 \\
\hline University of Leeds & 77.4 & 29.20 & Leiden University & 44.28 & 125.84 \\
\hline Université Catholique de Louvain & 77.25 & 29.46 & University of Groningen & 41.29 & 142.19 \\
\hline
\end{tabular}

DEA 2. Academic efficiency analysis. In this second DEA analysis, a study of university efficiency in terms of academic efficiency has been carried out. The inputs used have been the same as in the previous case. However, an average of the $\mathrm{HiCi}, \mathrm{N} \& \mathrm{~S}$ and PUB values calculated in the academic ranking of the universities of the world (ARWU) have been used for the output. We have followed a variable-scale return model oriented towards output (BBC-output model). In the model, the Cooper rule has been fulfilled, since we have worked with 4 variable inputs and one output variable. Therefore, $\alpha>3$.

The results are shown in table 6 . In it, an ordering of the DMUs has been made according to the score and a column -target index of Shanghai- has been added, in which the level that should be determined by the averaged index $\mathrm{HiCi}, \mathrm{N} \& \mathrm{~S}$ and PUB.

Table 6-Results of the application of the DEA academic efficiency model

\begin{tabular}{|l|c|c|l|c|c|}
\hline \multicolumn{1}{|c|}{ Unit Name } & Score & $\begin{array}{c}\text { Target Shangai } \\
\text { Index }\end{array}$ & \multicolumn{1}{|c|}{ Unit Name } & Score & $\begin{array}{c}\text { Target Shangai } \\
\text { Index }\end{array}$ \\
\hline \multicolumn{1}{|c|}{1} & 2 & 3 & \multicolumn{1}{|c|}{4} & 5 & 6 \\
\hline Universitat Politècnica de Valèn & 100 & 0 & Leiden University & 81.08 & 23.32 \\
\hline Università di Padova & 100 & 0 & Alma mater Studiorum - Universit & 77.67 & 28.75 \\
\hline Universität Stuttgart & 100 & 0 & Cardiff University & 75.68 & 32.14 \\
\hline Université Catholique de Louvain & 100 & 0 & University of Copenhagen & 75.5 & 32.44 \\
\hline Trinity College Dublin, the Univ & 100 & 0 & The university of Manchester & 75.13 & 33.12 \\
\hline Technische Universität Dresden & 100 & 0 & University of Southampton & 75.1 & 33.15 \\
\hline Université Pierre et Marie Curie & 100 & 0 & University of Leeds & 73.75 & 35.60 \\
\hline Eth Zurich - Swiss Federal Insti & 100 & 0 & University of Groningen & 73.13 & 36.73 \\
\hline University of Oxford & 100 & 0 & Technical University of Munich & 71.49 & 39.89 \\
\hline University of Cambridge & 100 & 0 & Universidad Autónoma de Madrid & 69.62 & 43.62 \\
\hline Erasmus University Rotterdam & 96.8 & 3.32 & University of Oslo & 69.22 & 44.46 \\
\hline Imperial College London & 94.31 & 6.04 & University of Glasgow & 69.08 & 44.75 \\
\hline Ku Leuven & 92 & 8.69 & University College Dublin & 67.58 & 47.96 \\
\hline University of Bristol & 90.16 & 10.91 & Kit. Karlsruhe institute of tech & 65.97 & 51.59 \\
\hline
\end{tabular}


table 6

\begin{tabular}{|l|c|c|l|c|c|}
\hline \multicolumn{1}{|c|}{1} & 2 & 3 & \multicolumn{1}{c|}{4} & 5 & 6 \\
\hline Ghent University & 88.06 & 13.57 & University of Birmingham & 65.3 & 53.15 \\
\hline Maastricht University & 86.76 & 15.26 & Politecnico di milano & 65.16 & 53.49 \\
\hline Delft university of Technology & 86.58 & 15.51 & University of Zurich & 64.93 & 54.02 \\
\hline Universitat de Barcelona & 85.12 & 17.46 & University of Nottingham & 61.87 & 61.63 \\
\hline The university of Edinburgh & 83.73 & 19.44 & The University of Sheffield & 60.89 & 64.21 \\
\hline University of Amsterdam & 83.27 & 20.10 & The University of Warwick & 59.8 & 67.24 \\
\hline Aarhus University & 81.08 & 23.34 & Rwth Aachen University & 56.12 & 78.17 \\
\hline
\end{tabular}

DEA 3. Analysis of technological efficiency. In the third DEA analysis, a study was made of university efficiency in terms of technological efficiency. Work has continued with the following inputs: the number of undergraduate students, the number of postgraduate students and the number of professors. In this analysis, the output used has been the number of patents filed. The information has been obtained from World's most innovate universities. As in the previous analyzes, we have followed a variable-scale return model oriented towards output (BBC-output model). In the model, the Cooper rule has been fulfilled, since we have worked with 4 variable inputs and one output variable. Therefore, $a>3$.

The results are shown in table 7 . We have continued presenting an ordering of the DMU according to the score and a column -target patents- has been added, in which the level that their patents should increase to reach the optimal level of technical efficiency is determined.

Table 7 - Results of the application of the DEA technological efficiency model

\begin{tabular}{|l|c|c|l|c|c|}
\hline \multicolumn{1}{|c|}{ Unit Name } & Score & Target Patents & \multicolumn{1}{c|}{ Unit Name } & Score & Target Patents \\
\hline Università di Padova & 100 & 0 & Aarhus University & 32.47 & 207.99 \\
\hline Universität Stuttgart & 100 & 0 & The University of Manchester & 32.42 & 208.42 \\
\hline Trinity college Dublin. The Univ & 100 & 0 & University of Oslo & 31.97 & 212.75 \\
\hline Universitat Politècnica de Valèn & 100 & 0 & University of Nottingham & 31.21 & 220.45 \\
\hline Université Pierre et Marie Curie & 100 & 0 & University of Birmingham & 30.83 & 224.36 \\
\hline Technische Universität Dresden & 100 & 0 & Alma mater Studiorum - University & 29.52 & 238.79 \\
\hline University of Oxford & 100 & 0 & Erasmus University Rotterdam & 29.27 & 241.67 \\
\hline Eth Zurich - Swiss Federal Insti & 100 & 0 & The University of Edinburgh & 29.24 & 241.98 \\
\hline Imperial College London & 99.37 & 0.63 & The University of Warwick & 27.64 & 261.78 \\
\hline Ku Leuven & 96.22 & 3.93 & Leiden University & 26.37 & 279.28 \\
\hline Delft University of Technology & 93.15 & 7.35 & University of Southampton & 25.02 & 299.67 \\
\hline Ghent University & 76.59 & 30.57 & University of Amsterdam & 24.26 & 312.13 \\
\hline Kit. Karlsruhe Institute of Tech & 74.72 & 33.83 & Universidad Autónoma de Madrid & 24.24 & 312.51 \\
\hline Universitat de Barcelona & 71.78 & 39.32 & The University of Sheffield & 23.41 & 327.12 \\
\hline University of Cambridge & 65.59 & 52.47 & Rwth Aachen University & 22.86 & 337.47 \\
\hline Politecnico di Milano & 65.02 & 53.79 & Cardiff University & 22.46 & 345.23 \\
\hline Université Catholique de Louvain & 63.55 & 57.35 & University of Copenhagen & 21.9 & 356.70 \\
\hline Technical University of Munich & 48.03 & 108.21 & University of Groningen & 20.73 & 382.35 \\
\hline Maastricht University & 44.22 & 126.14 & University of Bristol & 20.3 & 392.69 \\
\hline University College Dublin & 41.81 & 139.19 & University of Leeds & 19.42 & 414.92 \\
\hline University of Zurich & 41.68 & 139.94 & University of Glasgow & 17.03 & 487.08 \\
\hline
\end{tabular}

DEA 4. Global efficiency analysis. Finally, in this fourth DEA analysis, a study of global university efficiency has been carried out, which encompasses labour, academic and technological efficiency. The inputs used were the number of undergraduate students, the number of postgraduate students and the number of professors. The outputs were the overall score calculated in the QS Graduate Employability Ranking, the average of the $\mathrm{HiCi}, \mathrm{N} \& \mathrm{~S}$ and PUB values calculated in the academic ranking of the world's universities (ARWU) and the number of patents obtained from the World's most innovate universities.

The model used is a return to variable scale oriented towards output (BBC-output model). In it, the 
Cooper rule has been fulfilled since we have worked with 4 variables inputs and three variable output. Therefore, $a>3$.

The results are shown in table 8 . We have continued presenting an ordering of the DMU according to the score and three columns have been added that indicate how much they should increase their level QS, ARWU and number of patents to be placed in levels of maximum efficiency. Also, it is observed that to achieve it, on some occasions they should dedicate fewer resources for a certain purpose, and increase them in other outputs. In these cases, the target yields negative values.

Table 8-Results of the application of the global efficiency DEA model

\begin{tabular}{|c|c|c|c|c|c|c|c|c|c|}
\hline Unit Name & ठ্ّ & 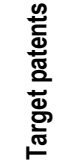 & 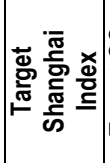 & 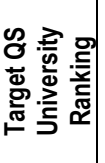 & Unit Name & む্ํํ & 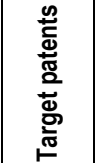 & 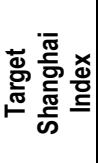 & 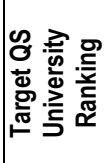 \\
\hline $\begin{array}{l}\text { University College } \\
\text { Dublin }\end{array}$ & 100 & 0.00 & 0.00 & 0.00 & $\begin{array}{l}\text { Technical University of } \\
\text { Munich }\end{array}$ & 61 & 63.75 & 0.00 & -22.30 \\
\hline Università di Padova & 100 & 0.00 & 0.00 & 0.00 & University of Oslo & 56 & 79.84 & 0.00 & 0.00 \\
\hline Leiden University & 100 & 0.00 & 0.00 & 0.00 & University of Zurich & 53 & 89.75 & 0.00 & -21.34 \\
\hline $\begin{array}{l}\text { Maastricht } \\
\text { University }\end{array}$ & 100 & 0.00 & 0.00 & 0.00 & The University of Warwick & 45 & 121.01 & 0.00 & 0.00 \\
\hline $\begin{array}{l}\text { Universitat } \\
\text { Politècnica de Valèn }\end{array}$ & 100 & 0.00 & 0.00 & 0.00 & University of Nottingham & 44 & 125.32 & 0.00 & -7.73 \\
\hline Universität Stuttgart & 100 & 0.00 & 0.00 & 0.00 & University of Birmingham & 41 & 141.17 & 0.00 & 0.00 \\
\hline $\begin{array}{l}\text { Trinity College } \\
\text { Dublin. The Univ }\end{array}$ & 100 & 0.00 & 0.00 & 0.00 & Rwth Aachen University & 39 & 158.10 & 0.00 & 0.00 \\
\hline Politecnico di Milano & 100 & 0.00 & 0.00 & 0.00 & $\begin{array}{l}\text { The University of } \\
\text { Manchester }\end{array}$ & 39 & 158.70 & 0.00 & -40.31 \\
\hline $\begin{array}{l}\text { Université pierre et } \\
\text { marie curie }\end{array}$ & 100 & 0.00 & 0.00 & 0.00 & Aarhus university & 37 & 166.72 & 0.00 & 0.00 \\
\hline $\begin{array}{l}\text { Delft university of } \\
\text { technology }\end{array}$ & 100 & 0.00 & 0.00 & 0.00 & The University of Sheffield & 35 & 188.88 & 0.00 & 0.00 \\
\hline $\begin{array}{l}\text { Imperial College } \\
\text { london }\end{array}$ & 100 & 0.00 & 0.00 & 0.00 & $\begin{array}{l}\text { Universidad Autónoma de } \\
\text { Madrid }\end{array}$ & 33 & 201.05 & 0.00 & 0.00 \\
\hline $\begin{array}{l}\text { Kit. Karlsruhe } \\
\text { institute of tech }\end{array}$ & 100 & 0.00 & 0.00 & 0.00 & The University of Edinburgh & 31 & 218.71 & 0.00 & -22.20 \\
\hline University of oxford & 100 & 0.00 & 0.00 & 0.00 & $\begin{array}{l}\text { Erasmus University } \\
\text { Rotterdam }\end{array}$ & 30 & 235.49 & 0.00 & -2.40 \\
\hline $\begin{array}{l}\text { Eth Zurich - Swiss } \\
\text { Federal Insti }\end{array}$ & 100 & 0.00 & 0.00 & 0.00 & $\begin{array}{l}\text { Alma Mater studiorum - } \\
\text { Universit }\end{array}$ & 30 & 238.79 & -5.39 & -32.05 \\
\hline \begin{tabular}{l|} 
Technische \\
Universität Dresden
\end{tabular} & 100 & 0.00 & 0.00 & 0.00 & University of Southampton & 29 & 239.41 & 0.00 & 0.00 \\
\hline Ku Leuven & 100 & 0.40 & 0.00 & -21.49 & Cardiff University & 28 & 260.59 & 0.00 & 0.00 \\
\hline Ghent University & 84 & 19.33 & 0.00 & 0.00 & University of Copenhagen & 28 & 261.42 & -8.25 & 0.00 \\
\hline $\begin{array}{l}\text { Université } \\
\text { Catholique de } \\
\text { Louvain }\end{array}$ & 81 & 23.91 & -9.50 & 0.00 & University of Amsterdam & 27 & 271.56 & 0.00 & -10.70 \\
\hline $\begin{array}{l}\text { Universitat de } \\
\text { Barcelona }\end{array}$ & 72 & 39.32 & -31.19 & -39.12 & University of Leeds & 24 & 315.75 & 0.00 & -15.55 \\
\hline $\begin{array}{l}\text { University of } \\
\text { Groningen }\end{array}$ & 68 & 46.26 & -21.52 & 0.00 & University of Glasgow & 22 & 346.94 & 0.00 & 0.00 \\
\hline $\begin{array}{l}\text { University of } \\
\text { Cambridge }\end{array}$ & 66 & 52.47 & -11.92 & -13.82 & University of Bristol & 21 & 377.96 & 0.00 & -13.38 \\
\hline
\end{tabular}

Finally, Table 9 shows Pearson correlation coefficient of the three output variables: employability, 
publications and patents. The correlation coefficient between patents and publications indicates a strong positive relationship between these two variables. This result is in accordance with recent studies which conclude that academic inventors are also more active in the generation of scientific knowledge (Bourelos et al., 2017[31]; Grimm and Jaenicke, 2015[32]; Magerman et al., 2015[33]).

Table 9 - Correlation matrix

\begin{tabular}{|c|c|c|c|}
\hline & employability & publications & patents \\
\hline employability & 1 & & 1 \\
\hline publications & 0.3663 & 0.7084 & 1 \\
\hline patents & 0.6076 & & \\
\hline
\end{tabular}

Conclusions and directions of further researches. In this article, we have carried out a DEA analysis that has allowed us to analyze the efficiency indexes of forty-two European universities related to their academic function, the labour insertion of their university graduates, technological innovation and finally a concept that has been defined and that encompasses all of them as is the global university efficiency. To this end, a nonparametric method has been used that has allowed us to define an optimal production function and the relative position occupied by each university analyzed with respect to it.

The results obtained have to be interpreted with caution. The ignorance of the exact functioning by which inputs are transformed into outputs implies that any modification in the definition of the components of the production function could yield different results.

In any case, highlight how in this article a university comparison is collected that moves away from most of the publications in terms of efficiency analysis since it contemplates a series of variables that summarize the three main functions that universities must fulfil in current societies such as providing quality employment to their graduates, providing companies with new forms of production and advancing science regionally.

The results provide not only show a list of universities in relation to the overall level of efficiency in which they are located. In addition, the analysis allows determining for each one of them what specific aspects should be focused to increase their global efficiency levels.

In this sense, we believe that this analysis should be completed in future works in a double aspect. On the one hand, carrying out a more detailed analysis of inputs/outputs variables that can give a more accurate view in determining the overall efficiency degree. On the other hand, carry out continuous analyzes over time, through which the evolution experienced by the universities could be determined, as well as introducing other types of concepts to the academic world, such as productivity analysis through statistical tools such as the Malmquist index. This index allows its calculation associated to two periods of time. It can also be broken down into two elements, such as, on the one hand, the deviations from the production boundary -technical efficiency; and, on the other, the movements of the frontier-technological change - (Marco-Serrano and Rausell-Köster, 2006 [34]).

1. Arcos, J. (1993). Evaluación de programas y políticas públicas. Metodología de evaluación. Avances en Contabilidad Analítica. Eficacia y Legalidad en la Gestión Pública, 113-158.

2. Álvarez, R. (2001). Modelos con eficiencia técnica variante en el tiempo. La medición de la eficiencia y la productividad, Pirámide, Madrid.

3. Farrell, M.J. (1957). The Measurement of Productive Efficiency. Journal of the Royal Statistical Society, 120, 253-290.

4. Buchelli, G. A., \& Marín, J. J. (2012). Estimación de la eficiencia del sectormetalmecánico en colombia: análisis de la frontera estocástica, Cuadernos de Economía, 31(58), 257-286.

5. Chirinos, A., \& Urdaneta, M. (2007). Medición de la eficiencia en el sector avícola mediante índices de Malmquist. Agroalimentaria, 12(25), 95-107.

6. Camilli, G., Vargas, S., Ryan, S., \& Barnett, W. S. (2010). Meta-analysis of the effects of early education interventions on cognitive and social development. Teachers College Record, 112(3), 579-620. 
7. Maza, F. J., Vergara, J. C., \& Navarro, J. L. (2012). Eficiencia de la inversión en el régimen subsidiado en salud en BolívarColombia, Investigacionesz Andina, 14, 386-400.

8. Charnes, A., Cooper, W. W., \& Rhodes, E. (1978). Measuring the efficiency of decision making units. European journal of operational research, 2(6), 429-444.

9. Banker, R. D., Charnes, A., \& Cooper, W. W. (1984). Some models for estimating technical and scale inefficiencies in data envelopment analysis. Management science, 30(9), 1078-1092.

10. Bessent, A. M., \& Bessent, E. W. (1980). Determining the comparative efficiency of schools through data envelopment analysis. Educational Administration Quarterly, 16(2), 57-75.

11. Emrouznejad, A., \& Yang, G. L. (2018). A survey and analysis of the first 40 years of scholarly literature in DEA: 19782016. Socio-Economic Planning Sciences, 61, 4-8.

12. Worthington, A., \& Dollery, B. E. (2000). Efficiency measurement in the local public sector: Econometric and mathematical programming frontier techniques. Queensland University of Technology, School of Economics and Finance.

13. Zhonghua, C., \& Ye, W. (2012). Research frontiers in public sector performance measurement. Physics Procedia, 25, 79379.

14. Abbott, M., \& Doucouliagos, C. (2003). The efficiency of Australian universities: a data envelopment analysis. Economics of Education review, 22(1), 89-97.

15. Avkiran, N. K. (2001). Investigating technical and scale efficiencies of Australian universities through data envelopment analysis. Socio-Economic Planning Sciences, 35(1), 57-80.

16. Bessent, A. M., \& Bessent, E. W. (1980). Determining the comparative efficiency of schools through data envelopment analysis. Educational Administration Quarterly, 16(2), 57-75.

17. Chu Ng, Y., \& Li, S. K. (2000). Measuring the research performance of Chinese higher education institutions: an application of data envelopment analysis. Education Economics, 8(2), 139-156.

18. Correas, A. G., \& Jorge, M. L. (2010). Análisis de diferentes medidas de la eficiencia investigadora y factores explicativos en las universidades públicas españolas. Investigaciones de Economía de la Educación, 5, 703-732.

19. Johnes, J., \& Li, Y. U. (2008). Measuring the research performance of Chinese higher education institutions using data envelopment analysis. China economic review, 19(4), 679-696.

20. Johnes, J. (2006). Measuring teaching efficiency in higher education: An application of data envelopment analysis to economics graduates from UK Universities 1993. European Journal of Operational Research, 174(1), 443-456.

21. Köksal, G., \& Nalçaci, B. (2006). The relative efficiency of departments at a Turkish engineering college: A data envelopment analysis. Higher Education, 51(2), 173-189.

22. Kuah, C. T., \& Wong, K. Y. (2011). Efficiency assessment of universities through data envelopment analysis. Procedia Computer Science, 3, 499-506.

23. Lee, B. L., \& Worthington, A. C. (2016). A network DEA quantity and quality-orientated production model: An application to Australian university research services. Omega, 60, 26-33.

24. Leitner, K. H., Prikoszovits, J., Schaffhauser-Linzatti, M., Stowasser, R., \& Wagner, K. (2007). The impact of size and specialisation on universities' department performance: A DEA analysis applied to Austrian universities. Higher Education, 53(4), 517-538.

25. Marti, M. L., Puertas, R., \& Calafat, C. (2014). Calidad y eficiencia de las Universidades Públicas Españolas. Revista de estudios regionales, $99,135-154$.

26. Martín R. (2007). La eficiencia productiva en el ámbito universitario: aspectos claves para su evaluación. Estudios de Economía aplicada, 25(3), 791-811.

27. Sagarra, M., Mar-Molinero, C., \& Agasisti, T. (2017). Exploring the efficiency of Mexican universities: Integrating data envelopment analysis and multidimensional scaling. Omega, 67, 123-133.

28. Taylor, B., \& Harris, G. (2004). Relative efficiency among South African universities: A data envelopment analysis. Higher Education, 47(1), 73-89

29. Warning, S. (2004). Performance differences in German higher education: Empirical analysis of strategic groups. Review of Industrial Organization, 24(4), 393-408.

30. Wolszczak-Derlacz, J. (2017). An evaluation and explanation of (in) efficiency in higher education institutions in Europe and the US with the application of two-stage semi-parametric DEA. Research Policy, 46(9), 1595-1605.

31. Bourelos, E., Beyhan, B. and McKelvey, M. (2017). Is the prominent scientist the one who becomes an inventor? A matching of Swedish academic pairs in nanoscience to examine the effect of publishing on patenting. Research Evaluation, 26(2), 144-156.

32. Grimm, H. M. and Jaenicke, J. (2015). Testing the causal relationship between academic patenting and scientific publishing in Germany: Crowding-out or reinforcement?. The Journal of Technology Transfer, 40(3), 512-535.

33. Magerman, T., Van Looy, B. and Debackere, K. (2015). Does involvement in patenting jeopardize one's academic footprint? An analysis of patent-paper pairs in biotechnology. Research Policy, 44(9), 1702-1713.

34. Marco-Serrano, F., \& Rausell-Köster, P. (2006). Productivity Analysis in the Spanish Cultural and Leisure Industry: A Regional Perspective/Análisis de la productividad en el sector de la cultura y el ocio español: una perspectiva regional. Estudios de Economía Aplicada, 24, 635-24á. 
М. Б. Канто, д.е.н., Університет Кадісу (Кадіс, Іспанія)

Л. Б. Лопес, Ph.D. Університет Кадісу (Кадіс, Іспанія).

Рейтинг глобальної ефективності найкращих університетів Європи

Діяльність будь-якого суб'єкта господарювання повинна базуватися на такому співвідношенні доходу до суми пов'язаних з ними витрат, при якому управління матеріальними та нематеріальними активами дозволяє досягати максимального обсягу виробництва при мінімальному обсязі залучених ресурсів. В рамках даного дослідження проведений аналіз ефективності діяльності закладів вищої освіти. Об'єктами дослідження є 42 найкращих університета Європи. Аналіз наукової літератури з теми дослідження дозволив авторам стверджувати, що невирішеними залишаються ряд теоретичних і прикладних проблем, пов'язаних з оцінкою ефективності діяльності закладів вищої освіти, зокрема врахування трьох основних функції університетів у XXI столітmі, таких, як: підвищення рівня працевлаштування випускників, передача та розширення наукових знань, а також модернізація національної економічної системи шляхом поліпшення бізнес-клімату. у роботі відповідно до поставлених завдань використано непараметричний метод порівняльного аналізу (data envelopment analysis (DEA)), який дозволяє визначити відносне положення кожного 3 досліджуваних університетів за рівнем ефективності порівняно з максимальним (ідеальним) рівнем ефективності, а також визначити основні напрямки ії підвищення. Авторами запропоновано здійснювати порівняльний аналіз ефрективності діяльності закладів вищої освіти за чотирма напрямками: ступінь працевлаштування випускників - DEA 1 «Аналіз ефрективності праці»; публікаційна активність - DEA 2 «Аналіз академічної ефективності»; патентна активність - DEA 3 «Аналіз технологічної ефективності»; інтегральна оцінка з урахуванням трьох попередніх складових - DEA 4 «Глобальний аналіз ефективності». Суб'єктами, які сформували основні вхідні параметри побудованої виробничої функиії методу DEA, стали: студенти, аспіранти, вітчизняні та закордонні викладачі. В якості вихідних параметрів моделі прийнято рівень працевлаштування випускників, публікаційну та патентну активність університетів. Використання кореляційного аналізу дозволило авторам відзначити високий ступінь лінійної залежності між університетами, що забезпечують найкращі результати в академічній та технологічній ефективності.

Ключові слова: рейтинг, університет, працевлаштування, метод порівняльного аналізу, патенти, публікації. 